\title{
Putting the dead to work: making sense of worker suicide in contemporary French and Francophone-Belgian film
}

\author{
Martin O'Shaughnessy (martin.oshaughnessy@ntu.ac.uk) \\ Department of English, Media and Creative Cultures, Nottingham Trent University, Clifton \\ Lane, Nottingham NG11 8NS
}

\begin{abstract}
Contemporary French and Francophone Belgian cinema has produced a wave of worker suicides that outdoes even Jean Gabin's repeated cinematic deaths of the later 1930s. This article discusses its significance in the context of neo-liberalism and develops an analytical tool-kit for making sense of it, taking its main theoretical inspirations from Slavoj Žižek's theorisation of violence and Carl Cedeström and Peter Fleming's analysis of worker suicide, but also drawing on Michel Foucault's account of parrhesia as the scandalous living of another life in this life. The article suggests that most of the films considered use the apparently subjective violence of worker suicide to force the unseen violences of neo-liberal labour into view, while only a few move beyond this denunciatory position to probe both what a parrhesiastic exit from neo-liberal labour, a killing of the worker-in-the-self, might look like and all that prevents it.
\end{abstract}

Keywords: Worker suicide; violence; neo-liberalism; Žižek; Foucault; parrhesia

Back in 1999, Rosetta, the Dardenne brothers' story of a young woman struggling to find stable employment and finally attempting to kill herself, burst on the scene at Cannes, carrying off the Palme d'Or and the prize for best actress (Émilie Dequenne). Sixteen years later, Vincent Lindon, the star of Stephane Brizé's La Loi du marché/The Measure of a Man (2015), won the Cannes prize for best actor for his role as an unemployed man in his early fifties who walks away from the job he has finally got, as a supermarket security-guard, after another employee has killed herself without any of the company's practices seeming to change as a result. In between these two films, other failed, abandoned and successful work-related suicides seem to have piled up in French and Franco-Belgian film: Selon Matthieu / To Matthieu (Xavier Beauvois, 2000); L'Emploi du temps / Time Out (Laurent Cantet, 2001); Sauf le respect que je vous dois / Burnt Out (Francois Godet, 2006); La Question humaine / Heartbeat Detector (Nikolas Klotz, 2006); Le Père de mes enfants / Father of My Children (Mia Hansen-Løve, 2009); De bon matin / Early One Morning (JeanMarc Moutout, 2010); Article 23 (Jean-Pierre Delépine, 2010); Ma part du gâteau / My Piece of the Pie (Cédric Klapisch, 2011); Le Grand Soir (Gustave Kervern and Benoît Delépine, 2012); Deux jours, une nuit / Two Days, One Night (Luc and Jean-Pierre Dardenne, 2014); Near Death Experience (Kervern and Delépine, 2014). To this not necessarily exhaustive list, one could add at least one high-quality, made-for-television film, Fabrice Cazeneuve's Seule I On Her Own (2008) and two more recent works, a television to cinema cross-over film, Isabelle Adjani vehicle Carole Matthieu (Louis-Julien Petit, 2016), and Corporate, a 2017 cinema release from first-time director, Nicolas Silhol. ${ }^{1}$ These 'worker suicide films' resist being corralled into any given genre and share no particular stylistic traits. Most could be labelled dramas but several are comedies, whether lighter or darker. A number might be 
called social realist but others (Kervern and Delépine's works, La Question humaine, Carole Matthieu) would resist that appellation for a range of reasons. Suicides have varying degrees of prominence and narrative functions in their stories. A suicide attempt is the prelude to the main story in Ma part du gâteau. Successful suicides trigger revenge or investigation narratives in Sauf le respect que je vous dois and Selon Matthieu. A failed suicide is a turning point of the Dardennes' Deux jours, une nuit but the culmination of the narrative of their Rosetta. In some cases, the suicidal character is the main protagonist (Rosetta, De bon matin) while in others the focus is on the reaction of other characters whether family (Seule) or colleagues (Sauf le respect que je vous dois). Some (the Dardennes' films, Ma part du gâteau) focus specifically on proletarian victims or near victims and lend themselves to class-centred readings. Others, however, are about higherranking employees, whether bankers (De bon matin), executives (La Question humaine) or management consultants ( $L^{\prime} E m p l o i d u$ temps) and raise broader questions about the nature of contemporary labour.

This recurrence of the worker suicide motif is truly remarkable and, outside of the suicide-prone Jean Gabin of later 1930s French film, has few if any cinematic precedents. There are certainly worker suicides in legendary leftist works such as Stachka / Strike (Eisenstein, 1925) and Kuhle Wampe / Whither Germany? (Dudow, 1932), but isolated deaths in these films are melodramatic preludes and Manichean supplements to more epic narratives of collective revolt or mobilisation (Gaines 1996, 61-67). The fact that contemporary cinematic suicides are not taken in hand in this way undoubtedly demands elucidation. They can certainly be connected to the broader context of a neo-liberal workplace increasingly associated with social suffering and the more specific context of high-profile worker suicide waves in companies like France Telecom and Renault (see, for example, Waters 2014). However, given the diversity of genres, foci and narrative arcs found in the films, one would hesitate to attribute a homogenous cultural meaning to them or to explain them simply as symptoms of their socio-economic circumstances. Although they are clearly to some extent products of their period, they are also creative reactions to it and, as such, invite evaluation in terms of the consequences of their formal and thematic choices.

This article therefore sets us to provide what one might call an analytical tool-kit, something that will differentiate between the films discussed and evaluate the choices they make while elucidating their broader cultural significance. I suggested elsewhere that what has characterised the framing of struggle in French film since about 1995, the period when a new wave of more politicised films started to appear, is the absence of mediating instances (parties, unions, an elaborated political language), the loss of a sense of history (a leftist tradition, a progressive opening onto the future), and a concomitant focus on the individual and his or her body in their immediate collision with systemic violences, a shift which I summarised as a move from an aesthetic of totality to an aesthetic of the fragment (O'Shaughnessy 2007, 99-130). Developing that analysis, I later argued that Slavoj Žižek's tripartite categorisation of violences could help illuminate how films were able to articulate subjective, symbolic and systemic violences and thus avoid a politically disabling enclosure within the fragmentary and the immediate (O'Shaughnessy 2010, 46-50). Building on this earlier work, I will suggest here that the same tripartite understanding of violences can help us make sense of how films deal with the apparently subjective violence of worker suicide. Recognising, however, that suicide is a very specific form of violence that requires more targeted theoretical tools, I will turn to Carl Cedeström and Peter Fleming's Žižek-inspired 
categorisation of worker suicides to differentiate between the forms of suicide shown in the films, attaching particular importance to suicides that involve a killing of the worker-in-theself rather than the self-in-the-worker and thus point to a life beyond neo-liberal labour and the subjectivities associated with it. I will also make use of the notion, expressed in the title of Cedeström and Fleming's book, Dead Man Working, to point to the fourth, slower, but no less deadly, kind of suicide represented by the remaking of self to fit the dominant order (Cedeström and Fleming 2012, 55-67). Rounding out my tool-kit, I will suggest a further tripartite division, this time between moralising, ethical and political framings of worker suicide. Although this division bears some risk of reductionism, I believe it provides productive ways to differentiate between films. I will also argue that the way in which films may resist neat categorisation bears its own important lessons about the period we are living in.

\section{Subjective, symbolic and systemic violence}

Žižek begins Violence: Six Sideways Reflections by naming the three categories of violence, the subjective, systemic and symbolic, that the rest of the work will develop. As he explains, subjective violence occurs when, through acts of crime, terror, civil unrest or international conflict committed by a clearly identifiable agent (or subject), the 'normal', 'peaceful', order of things is disrupted. Our usual, cued response to this kind of disorderly outburst is to be fascinated and horrified by it, seeing it is a challenge to the kind of liberal tolerance that has become the dominant norm in western societies (Žižek 2008, 1-3). Unsurprisingly, for those who know his work, Žižek enjoins us to mistrust this immediate reaction. He reminds us that subjective violence is simply the most visible of the triumvirate of violences. We are blinded if we stare too directly at it. Instead, we need to look at it 'sideways', as his book's title reminds us. As he notes, 'the overpowering horror of violent acts and empathy with the victims inexorably functions as a lure which prevents us from thinking' $(2008,3)$. We need to return our attention to the two forms of objective violence, the systemic and the symbolic, which provide the ground from which subjective violence arises and against which it is defined (2008, 1-10).

What of the two objective violences? Systemic violence, as its name implies, relates to 'the often catastrophic consequences of our economic and political systems' $(2008,1)$. Although by no means a purely modern phenomenon, it takes on a more impersonal but no less deadly shape with the rise of capitalism. Capitalism's insatiable drive to expand may simply seem an abstraction, especially when, as now, financial capital is in the ascendancy. Money seeks dispassionately to make more money. Speculative bubbles arise, apparently regardless of real-world circumstances. Future gains and losses are gambled upon. But the profit drive, far from simply being a dominant ideal, is in fact the real abstraction that moulds our socio-economic order, 'provides the key to real-life developments and catastrophes' $(2008,11)$ and 'automatically' creates 'excluded and dispensable individuals' $(2008,12)$. The more capitalism dominates, the more its violence seems to be the normal, 'peaceful' state of affairs, something that becomes the unquestioned background for more subjective, disruptive forms of violence.

Symbolic violence, the third element of the triptych, relates particularly to language. Language, as Žižek sees it, is neither a neutral and intrinsically peaceful communicative medium, nor a secondary distortion that merely comes to overlay or add to 'real' acts of violence. It is in fact, 'the ultimate resort of every specifically human violence' $(2008,55)$. He explains this perhaps counter-intuitive point by citing the example of anti-Semitic pogroms, 
noting that what the perpetrators find intolerable is not the immediate reality of the Jew in front of them but the fantasmatic image or figure of the Jew in circulation in their tradition. Ramming home the point, he adds: 'Reality itself in its stupid existence, is never intolerable: it is language, its symbolisation, which makes it such' $(2008,57)$. By naming things, by creating their seeming essence, language exercises a primordial violence woven into the taken-for-granted fabric of our world $(2008,55)$. While subjective violence might seem external to the normal systemic and symbolic order, the transgression that confirms the rule, the true relationship lies within transgression itself in the interaction between particular (subjective) transgressions and the absolute transgression which appears as its opposite, as the legitimate order of things $(2008,55)$.

In its apparent isolation, a killing of the self by the self, suicide seems an almost perfect example of subjective violence, a personal tragedy that causes intense local pain and disruption but has no broader systemic or symbolic resonance. Yet, since Durkheim's landmark work on the topic (Le Suicide, 1897), a whole sociological tradition has sought to relate suicide to social structures and their evolution. Durkheim himself famously associated it with social anomie and regulation, seeing it as an indication of the broader capacity of societies to integrate their members and structure their lives, more or less supportively or oppressively. Putting Durkheim into Žižek's framework, one could say that he struggled on the symbolic level to reconnect apparently subjective violence to the systemic. Something similar might be said of the worker suicide films we are considering. To some extent or another, and most obviously when they are investigation narratives, like Sauf le respect que je vous dois, the films work at the intersection of the three violences, carrying out their own symbolic labour to reconnect the subjective and the systemic, using an excessively visible violence to point to a much greater, hidden violence, the 'absolute transgression' of the economic system. By so doing, they are of course feeding into broader societal debates between those who, in an act of linguistic violence, name workplace suicide a tragic 'accident' or even, as France Telecom chief executive Didier Lombard infamously did, a 'fashion', and those who link it to the oppressiveness of contemporary working practices (Dejours 2009; Waters 2014).

Žižek's analysis clearly builds on important traditions in critical thought. In their different ways, Marxist, anarchist, feminist, anti-racist and anti-colonial thinkers would all point to the violence inherent in the apparently peaceful functioning of the status quo, seeing violence either as an implicitly threatened, physical response to any challenge to the dominant order, a weaker claim, or as intrinsic, in its systemic and symbolic forms, to the dominant order itself, a stronger claim of the type made by Žižek himself. The difference between the weaker and stronger claims (violence as a threat held in reserve or as constitutively present) points to two related lines of critique that could be directed at Žižek: firstly, that he over-extends the concept of violence and thus risks blurring different forms of domination; secondly, that by so doing, he implicitly justifies the excesses of insurrectional or revolutionary violence. This is the thrust of the response to Žižek's text written by Harry van der Linden (2012). As if anticipating this critique, Hannah Arendt had already argued that it is vital to keep concepts like violence and power analytically separate, with the latter reserved to describe the collective influence of groups achieved through argument and negotiation. Far from being synonymous with violence, power is, Arendt argues, its radical opposite. It is when people withdraw their consent for the existing order that power is lost and violence must be deployed to keep them in place (Arendt 1970). While it is certainly worth asking whether Žižek does indeed over-extend the concept of 
violence, one should note the considerable critical and explanatory power of the concept in its extended form and its ability to connect apparently isolated or atypical acts of subjective violence to their systemic and symbolic contexts while pointing to the normally hidden 'violences' of the latter. One should also note that, precisely because Žižek expands the concept of violence, it is simplistic to accuse him of advocating violence in its more conventional acceptation. He certainly argues for a violent (radical) rejection of the status quo, but that is not the same thing as arguing for physical violence. In any case, the justification or not of insurrectional violence lies well outside the scope of what I am arguing here. What draws me to Žižek's tripartite schema is its capacity to unpick how a body of films knowingly deploy worker suicide, a surface violence, to force deeper systemic and symbolic violences to the surface. The theory responds to something already implicit in the films rather than forcing them to fit an externally imposed mould.

\section{Three kinds of worker suicides and the working dead}

In The Fragile Absolute, Žižek delineates three variants of suicide, building upon the Lacanian division between the real, the imaginary, and the symbolic. Suicide in the real, a violent passage à l'acte, occurs when, in a denial of its own incompleteness, the subject identifies directly with the object of desire, thus suppressing itself as a necessarily empty frame. Then, there is suicide that 'bears a message' about political, erotic and other disappointments to the Other. This suicide, as Žižek sees it, is fundamentally imaginary, in that it is sustained by narcissistic satisfaction derived from the imagined effect on those chosen as witnesses of the victim's death which the victim himself or herself will not be able to observe for obvious reasons. Finally, there is symbolic suicide, which is not simply a symbolic death (not really dying) but equates to a radical cutting off from the symbolic network that defines the subject's identity $(2000,27-30)$.

Cedeström and Fleming adapt this general typology to their analysis of the specific modalities of worker suicide. They cite, as an example of suicide in the real, 'the banker who ends his life when the economy dips [...] conveying a complete identification with the market and the failing firm'. They comment that this act 'signifies only itself', adding that, 'there is no distance between the suicide's identity and the failed object that has slowly become their life (work, the stock market, the bank account)'. Moving on to imaginary suicide, they cite the suicides at France Télécom, noting how, 'in this type of suicide the Other is addressed directly, usually with texts or methods of termination that are horrendously graphic' $(2012,65)$. The problem, however, is that such suicides need to imagine that one is present at one's own funeral and are addressed 'to an undeserving Other who in the end doesn't even care' $(2012,66)$. The third suicide, the symbolic variant, is more potentially liberatory. Rethinking life 'from the perspective of death', it recognises that 'it is only by killing ourselves, as we know it (sic), that we could start anew'. Because we have effectively internalised the norms of the corporation, 'it is not enough for us to kill the boss or set the corporation on fire [...] [U]ltimately, we are the boss; we are the embodiment of the corporation. To kill ourselves, symbolically, is to kill the boss function' $(2012,66)$. Having internalised our own enslavement and built our sense of self around it, we must effectively unlearn life to open new vistas. The only genuinely productive worker suicides, therefore, are those which kill the worker-in-the-self, no matter how painful that might be, rather than the self-in-the-worker. In the latter case, one can opt for immediate self-immolation or the long slow suicide involved in giving up on those parts of one's life not 
already colonised by labour. This latter living death takes us back to the 'dead man working', as Cedeström and Fleming's book title aptly puts it.

\section{Moral, ethical and political appropriations}

The next three sub-categories, the moral, ethical and political, are defined in a knowingly more schematic manner. In some ways, they might seem like rather blunt tools. I believe they are nonetheless useful in their capacity to pull out differences in the essential thrust of the films. By moral, I essentially mean moralising, along lines discussed by Wendy Brown (2001). Brown suggests that a moralising politics, in reality an anti-politics, arises when there is a crisis of political teleology rooted in 'a misrecognition of the political logics now organizing the world, a concomitant failure to discern any direction for action, and a loss of any clear object of political desire' (Brown 2001, 29). In such a context, Brown observes, 'the perverse triple consequence is a kind of moralizing against history in the form of condemning particular events or utterances, personifying history in individuals, and disavowing history as a productive or transformative force' (Brown 2001, 30). In other words, rather than putting in the painful work of understanding the contemporary order and our own stake within it, and the even harder work of imagining new ways forward, we fall back on a comforting but impotent attribution of blame and virtue to various emblematic figures or institutions. Such moralising, already a consequence of the apparent impossibility of opposing triumphant neo-liberalism and the left's lack of an over-arching oppositional project, characterised much of the reaction to the 2008 crisis which invited us to focus blame on selfish, irresponsible banks and bankers rather than neo-liberal capitalism and our implication in it.

In contrast to this sterile moralising, a suitably rigorous ethics might seem to offer more promising ways forward. All depends of course on how the ethical is framed. The dominant form of ethical questioning in contemporary film studies tends to concentrate on relations between self and other, often drawing on the work of Emmanuel Levinas. The undoubted power of a Levinasian ethics is its capacity to mobilise the uncomfortable encounter with the other, in her or his radical and irreducible unknowability, and to challenge the boundaries, understandings and norms of a world centred on the self. The problem with such an ethics is that it too often frames encounters with others in interindividual terms, thus neglecting or downplaying the broader grounds on which any encounter must inevitably take place. It also tends to emphasise, as Alain Badiou notes, human vulnerability, the capacity to be harmed, rather than the capacity to create the new (Badiou 2003, 34-52). Stripped of any sense of how individual behaviour might be articulated with collective action directed towards systemic change, an ethical openness to otherness, no matter how apparently radical, risks morphing into a moralising supplement to the status quo, neo-liberalism being more than able to accommodate infinite shades of difference, provided the latter are framed in ways that pose no challenge to economic profitability (Badiou 2003, 50-51). An alternative account of ethics, one that productively probes the relationship between ethics and politics, is that developed by Foucault in his late work around the concept of the care of the self, and particularly of parrhesia as a scandalous truth-telling and self-endangering embodiment of another life in this life (Foucault 2012). In the context of my analysis of Kervern and Delépine's Le Grand Soir, I will suggest that parrhesia can profitably be articulated with suicide in the symbolic to anticipate what an exit from neo-liberal labour might look like, the work on the self involved, and the limits of any purely individual escape attempt. I will also suggest that a 
limitation of some of the other films discussed is their failure to probe either the problematic articulation of politics and ethics or the extent of the work on the self required for an exit from neoliberal labour.

What of the political? To begin with, it is advisable to separate the question of the political efficacy of a film from the way in which it represents issues and addresses its spectators. Depending as it does on the contingent articulation of a film's reception with collective political action, the former, as Jacques Rancière notes, cannot be dictated by formal choices nor derived from textual analysis (2008, 56-92). What textual analysis can assess is the degree to which representation of a phenomenon like worker suicide is able to engage with the systemic and to figure what it shows as the contingent product of a particular set of power relations and thus open to change. Indeed, given that pessimism has to some extent been enlisted by neo-liberalism in the age of austerity, and that any desire to produce a fairer world is seen as doomed to make things worse, it could be argued that the key role of progressive film has become not simply critique but the opening of alternative horizons. At the same time, a key element of any political film is its capacity to disrupt spectators' certainties and to invite them to consider their own imbrication in systemic dynamics.

This tripartite division is knowingly schematic and will need to be nuanced when applied to individual films. Clearly, there should be no neat dividing line between politics and ethics. Political questions about principles governing collective action and interaction inevitably overlap with ethical questions about how we choose to live our lives. Ethical questions about how we respond to others or relate to ourselves should open up political questions, given that we are always shaped by socio-political contexts and engage with others in circumstances which are never simply inter-individual. Similarly, when an ethics, no matter how demanding it may appear to be, becomes a form of contemporary common sense and loses its power to challenge, it risks taking on moralising tones and setting up Manichean and self-sustaining oppositions, not least between systemic monstrosity and our absolute duty of care towards vulnerable individuals. Closer engagement with the films may help us work through some of these problems.

\section{Dead workers talking}

The first work I will discuss is Cazeneuve's made-for-television film Seule, not simply because, shown in 2008, it sits nicely at the midpoint of the period I am concerned with, but because it is also in many ways indicative of broader trends. It begins by showing a smart couple, Brigitte (Barbara Schulz) and Éric Nardier (Jean-Pierre Lorit), arriving at the administrative offices of La Codotex, a component manufacturer. Brigitte struggles to get the stressed-looking Éric to talk to her before they go to their separate offices. However, when Brigitte is at lunch, she learns that Éric has jumped from his office window. She rushes down to where he has landed only to see him being lifted into an ambulance. On the dark tarmac, we see the chalk outline of his body with a small pool of dark red blood by the head (Figure 1). He will die in hospital. The hollow outline anticipates this loss but also suggests that his death is an empty signifier that people will struggle to fill with their preferred meanings. In some ways, it stands in for other absent and silenced worker bodies in French film and attempts to make them speak, even in the absence of their owners.

To begin with, everyone gathers round Brigitte. Her two office-mates are upset and supportive. The company's Directeur des Ressources Humaines (DRH or Human Resources Manager) attends the funeral. The Managing Director sends flowers. Discord, to the extent 
there is any, comes from within her family circle: her mother-in-law thinks her son remained depressed by the divorce from his first wife. But the film itself opens up a potential alternative account when it presents us with a montage of to-camera witness statements from five workers in the company, four of whom imply some connection to working conditions: one suggests there may have been a frustrated desire for recognition; another notes that the workers are stressed by continuous evaluation of their performance; a third cites target-driven management; the fourth says that the employees work with a visceral sense of hate ('la haine au ventre'). The gap between the different accounts opens more overtly when the DRH asks if Brigitte has found a letter at home, inquires whether the labour inspectorate have talked with her yet and warns her that she may come under pressure from a 'tigerish' shop steward. Brigitte suggests that, given that her husband killed himself at work, they should look for a letter there. Over lunch, one of her two workmates, Marie-Hélène, suggests that it is pointless to pursue the truth. Brigitte is indignant. Two trade unionists join them, including the 'tigerish' woman: the latter tells Brigitte that there have been three earlier suicides associated with the company. Two were not in the workplace and so cannot be counted, objects Marie- Hélène. Later, the female shop steward tries to connect the suicide to the broader context of individual evaluation, performance related pay and a culture of mutual surveillance. Brigitte is not ready for such an account. Nor is she receptive when her father, an old leftist, seeks to insert her husband's death into a longer history of class struggle within which some always win and others always lose. Things have changed, she objects. Because of globalisation, the company must fight to survive.

This discursive to and fro tilts more decisively when the DRH appears on television and affirms that the suicide was not linked to overwork but may have had its roots in the private sphere, family disagreements or even problems within the couple. When confronted by an angry Brigitte, the DRH summons Christophe, Éric's old workmate, and rival for promotion, to bear witness to the dead man's regrets over the failure of his first marriage. Soon afterwards, when Brigitte finally manages to obtain her husband's mobile phone, she finds details of work-related matters that might have cast a different light on the suicide have been wiped from it, an action that Christophe confesses to having carried out. Brigitte now argues with her office mates. By sharing details of conversations about problems within her marriage, they have helped the company bolster their version of the story. Brigitte visits the widow of the man who committed suicide on company premises three years earlier: the woman explains how she felt completely isolated and allowed the company to convince her the suicide was somehow her fault. Brigitte's final recourse is to take the company to court and talk to the press. The trade unions are divided in their response to the former decision. While the woman shop steward is sympathetic, the male one is very critical. He thinks the company is just looking for an excuse to transfer production overseas and feels defence of jobs must be their priority. The appearance of the newspaper report with a headline denouncing the wave of suicides at La Codotex brings matters to a close. Brigitte is summoned to the DRH's office and summarily told she will have to leave. The film's title is now fully justified. She has been abandoned by all those who seemed to be with her and is alone.

The film's fundamental dynamics can be expressed in terms of Žižek's three violences. The suicide appears to be an act of subjective violence. The chalk outline on the tarmac and the pool of dark red blood seem to be foreign, intrusive objects against an orderly background of cold blues and greys, concrete and glass surfaces, and elegant 
business clothes. All the company's efforts are directed towards maintaining the strangeness of the death as a tragic, messy interruption to the normal, 'peaceful' state of affairs: the dead man's personal problems are amplified and broadcast while evidence of work-related stress and the intense pressure put on individuals to compete is downplayed, hidden or erased. On the other hand, all Brigitte's efforts are directed towards connecting her husband's death to the hidden violences of the workplace. In other words, Brigitte struggles on the symbolic plane to force systemic violences into view even as the company fights to prevent the suicide being symbolised in systemic terms. At the same time, through her deliberate marginalisation and her implied contribution to the suicide, Brigitte herself is exposed to both systemic and symbolic violence.

\section{INSERT FIGURE 1}

Figure 1: An outline awaiting its symbolic appropriation (France 2).

Where then does Cedeström and Fleming's tripartite categorisation of worker suicide fit in? Although we are never quite sure why Brigitte's husband, Éric, kills himself, the film strongly implies that it is to do with workplace pressure and forced competition between employees. It thus approximates most closely to Cedeström and Fleming's first category, that of workers who over-identify with their work and kill themselves in a blind passage à l'acte. What Brigitte does, in her attempt to give meaning to her husband's act, is to move it into the second category, that of the imaginary, whereby the gesture becomes a way of transmitting a message to the dead man's children, the company and the broader society, even if the man cannot see the impact of the message on the witnesses and neither the company nor perhaps the broader society care. Yet, the film contains a second, quieter and perhaps more interesting suicide, that of the woman herself. In her pursuit of truth and justice rather than a quiet life, she effectively detaches herself from any loyalty to the firm and ambitions she may have had within it. She thus commits a kind of suicide in the symbolic, a gesture confirmed when she is isolated and expelled from the company, no longer a colleague or worker. At the same time, those left behind confirm their own acceptance of a kind of living death. By refusing to stand against the company's murderous logics, by choosing preservation of their job and the workplace, over any broader commitment to colleagues or principle, they kill at least a part of themselves. The material correlate of that deadness is the cold colours, sterile surfaces and hard, unyielding materials of the company building.

How should we evaluate the film's framing of the issues it raises? It certainly participates in broader French debates about workplace suffering in general and worker suicide in particular by bringing systemic violence into view. ${ }^{2}$ As such, it has a certain political valence, although we have no way of isolating any particular effectiveness it may have had. It also has a clear ethical dimension: the woman courageously commits to uncovering the truth about her husband's death and seeking justice for him, despite the personal consequences for her. The film shows an implicit awareness that this ethical stance ultimately leaves her alone and thus risks sterility without some broader, accompanying mobilisation. But, the woman's killing of the worker-in-the-self is shown as an accidental and unwelcome consequence of her ethical commitment and is not accompanied by a more meaningful probing of all that ties her to the workplace and its logics. At the same time, the film is never entirely clear whether what is shown is an aberration of neo-liberal capitalism 
or a more intrinsic consequence of its fundamental logics. As a result, in its opposition of a plucky underdog against an unscrupulous management, it ultimately risks drifting into a sterile moralism, a consensual, Manichean opposition of the good little people and the evil corporation. This ambiguity, I would suggest, is as much a sign of the times as it is of any intrinsic limitations of the film. At a time when a collective, transformational political project is lacking, and when no meaningful opening onto an alternative future is available, are we not indeed condemned to vacillate between sterile moralism, unproductive ethical stances and the inchoate murmurings of a more meaningful politics?

An ethical response to the violences of neo-liberalism can perhaps be found in purer form in the cinema of the Dardennes, with its avowed Levinasian inspiration. Murder and suicide have hung over the brother's work from La Promesse/The Promise (1996) to the recent Deux jours, une nuit and La Fille inconnue/The Unknown Girl (2016), although the murders are not always literally murders, and the suicides are never literally suicides due to the brothers' commitment to their characters and determination to offer them an ethical way forward. The incompleteness of the suicides makes the films particularly interesting from my point of view here. I will probe two of the brothers' films, Rosetta and Deux jours, une nuit, to develop these points.

Plunging down a corridor in pursuit of those who have sacked her, pursued by a camera that can never quite catch up, nor frame her adequately, Rosetta (Émilie Dequenne), the Dardennes' eponymous heroine, is born to the cinematic world in violence. She moves in a context in which useful places are rationed yet unemployment means exclusion, with people set in competition with each other, not to prosper, but simply to belong. The implicitly homicidal nature of this logic is driven forcefully to the surface in the crucial scene where she is tempted to let Riquet (Fabrizio Rongione) drown in a pond so that she can take his job selling waffles from a van at a bus station. She saves him, thus drawing back from physical murder, but proceeds to a symbolic assassination when she denounces him to his boss (Olivier Gourmet) for selling his own waffles, causing his sacking. She takes his job, thus acquiring a fragile toe-hold on social belonging at his expense. A furious Riquet, a visible manifestation of her guilt, pursues her relentlessly, often on his moped, its angry buzzing denying her any sense of peace. Rosetta is driven to a staggered suicide. She first rings the boss and tells him she no longer wants the job. To the extent that salaried labour is the current pre-condition of social existence, this is an act of self-erasure. She then shuts herself in her caravan and tries to gas herself. The film will not allow her to die: the gas canister runs out. As she returns to her caravan, lugging a fresh canister, Riquet arrives. She tries to brush him off but falls to the ground with the heavy container. Finally, she cries and allows herself to be helped. The film's closing moment thus opens a door onto a new, ethical form of human interaction based on mutual recognition of vulnerability and interdependency.

Deux jours, une nuit reworks core dynamics of Rosetta across a larger cast of characters. Sandra (Marion Cotillard), the heroine, is employed in a solar panel factory but has been off work after a bout of depression. In her absence, her sixteen fellow workers have found that they can cope without her by working longer hours. A ballot has been held requiring them to choose between her continued employment and an annual bonus which they all need, some to pay for essential expenses, others for home improvement or longed for consumer goods. Under pressure from the foreman, they have voted for their bonus, thus consenting to Sandra's elimination. Her friend persuades her to appeal to the boss for a fairer re-run of the ballot. He agrees. She has until Monday to persuade her colleagues. 
Urged on by her friend and her husband (Fabrizio Rongione), she visits each in turn, expressing understanding for their decision yet asking them to understand her position. Part way through her sequence of visits, she becomes disheartened and takes an overdose only to change her mind when she learns that another colleague has come out in support of her. After her husband and her friend have rushed her to the hospital, she recommences her repetitive but varied task of convincing each workmate in turn. When the ballot is re-run, the vote is evenly split. Impressed by this commitment from her fellow-workers, and not wishing to divide his workforce, the boss agrees to take her back but says that someone else, a more recently hired worker on a temporary contract, will have to go instead. Sandra refuses to be complicit in this elimination and leaves with her head held high, having relearned how to fight and the capacity of people to stand together. In its way, this latter decision is also a temporary form of suicide. Sandra has erased herself as a worker, for the time being at least.

How do the attempted suicides in these two works relate to each other and to my broader attempt to make sense of cinematic worker suicides? Firstly, the kind of intervention the films make in the framing of violence is clear. Both use precarious individuals, and especially their bodies, as canvases upon which to force systemic violences into view with the somatic (Rosetta's stomach cramps, Sandra's breathlessness), the kinetic (both women's constant movement through the world of the film) and embodied collisions of various sorts (the rescue from drowning in Rosetta, a fight between a father and son in Deux jours, une nuit) all being mobilised to make the pain and conflict caused by systemic logics visible and tangible. Within this broader context, the subjective violence of the attempted suicides has a logical place, signalling moments when systemic and symbolic violences become too much for individuals to bear. Subjective violence is thus used in familiar, melodramatic fashion to force objective violence into view.

The films' attempted suicides also work in a similar and complex fashion. Both initially equate to Cedeström and Fleming's suicide in the real; that is, the characters do not seek to send a message but simply over-identify with 'the failed object [neo-liberal labour, the company] that has slowly become their life' (Cedeström and Fleming 2012, 65 (my insertion)). Thus, Sandra mistakenly aligns herself with her own socially constructed disposability, masochistically assuming that some failing on her part (her depression) means she is no longer good enough (see Figure 2). Rosetta likewise aligns herself too closely with a system that sets people in ruthless competition and rations places: having initially overidentified with systemic murderousness, she effectively assumes her designated status as waste human when she tries to kill herself. Complicating matters, the suicide attempts are clearly endowed with an enforced publicness by their presence in films. They thus speak of the systemic violence done to characters who send a message despite themselves and without the need of help from a character within the diegesis such as the heroine of Seule.

\section{INSERT FIGURE 2}

Figure 2: Sandra over-identifying with her own disposability (Artifical Eye).

The Dardennes' two films share with Seule the presence, albeit under-developed, of Žižek's suicide in the symbolic, the act by which a person severs the ties which define their existing position in the symbolic order. Shortly before both end, the heroines either resign their job (Rosetta) or refuse to regain it by displacing someone else (Deux jours, une nuit). The way is thereby opened for them to effectively cut the ties that bind them to neo-liberal 
labour and to kill the worker-in-the-self. The problem is that the consequences of this more productive suicide in the symbolic are neither fully assumed nor obstacles to it confronted and worked through because of the films' resolute focus on the ethical (rather than the

political or the ethico-political). Rosetta's resignation is narratively tied to a refusal to replace (i.e. to symbolically kill) the other. Sandra closing refusal to replace a colleague is similarly motivated. What each film stages and plays out both across individual bodies, and in the collision between individuals, is an opposition between a radical ethical openness to the other in his or her vulnerability and a murderous and monstrous preference for the self. Because this opposition is Manichean and ultimately static, a binary choice rather than a complex co-mingling, the films are much nearer than it might initially seem to the kind of moralising that we found in Seule.

Deux jours, une nuit also comes very close to an inadvertent admission of the impasse that this kind of ethical framing represents. It shows that the ruthlessness that almost destroys Sandra is systemic. It shows too that all its characters are stitched into systemic logics by their desires, needs and vulnerability. It shows, finally, that people can only meaningfully find alternative ways forward by standing together, as the workers finally seem ready to do as the film ends. Yet, its steadfast, formally heroic pursuit of the logic of the individual face-to-face and its commitment to the Manichean opposition between openness and murderousness leave it no space to work through the consequences of the multiple, mundane compromises (the little suicides) to which we all consent on an everyday basis, nor to develop what a renewed collective opposition might look like, especially one that sought to move beyond a shared sense of vulnerability to something more assertively creative. When Sandra walks away from the workplace with renewed hope at the end of the film (see Figure 3), we might ask whether the film is not also walking away from the messy work of thinking through what an exit from neo-liberal labour might mean.

\section{INSERT FIGURE 3}

Figure 3: The satisfaction of walking away from work? (Artificial Eye).

Two films that, in their very different ways, do highlight the very hard work involved in rooting out the worker-in-the-self and the difficulty of sustaining any durable individual escape without systemic change are Cantet's L'Emploi du temps and Kervern and Delépine's Le Grand Soir. The former, an art-house drama, is the story of a high-performing management consultant, Vincent (Aurélien Recoing), who hides the loss of a job that he can no longer bear, seems on the point of committing suicide, but then returns to work. The latter, a decidedly off-beat comedy, centres on two brothers, 'Not' (Benoît Poolevorde), the 'oldest punk with a dog in Europe', and Jean-Pierre (Albert Dupontel), a conformist bed salesman who, at the end of his tether, tries to kill himself and fails. I will focus on each in turn.

Cantet's hero, in some ways, tries to have it all. He has reached the stage where the only thing he still enjoys is travelling from client to client and the sense of freedom that the road brings. Having been fired for carrying on driving rather than attending appointments, he hides the redundancy from his family and friends. He drives around aimlessly, sleeps in his car in car parks, and enjoys his freedom, even as he uses his mobile phone to tell his wife of tense, high-powered meetings and an exciting job opportunity in Switzerland. But he needs money. He persuades his father to lend him a large sum as a deposit for a fictitious apartment in Geneva and convinces old friends from business school to put money into 
similarly fictitious but supposedly highly profitable investments in the ex-communist East. It cannot last, of course. His father wants to visit the apartment he has put money into. His friends become nervous, want more details about the investments and start asking for their money back. A magical escape seems to be offered when Vincent is recruited to smuggle counterfeit goods over the border. He can pay people back but can still live outside conventional norms until, that is, the job loss is discovered. We then think he may kill himself: we see him get out of his car and walk into the night even as his wife proclaims the family's love for him over his mobile phone. We assume these family attachments draw him back in for the film's calm but the quietly chilling final scene sees him being interviewed for another high-powered job. The camera slowly tracks towards him in the last shot, tightening the frame and metaphorically showing his growing entrapment as, abandoning his attempt to break out of contemporary labour, he accepts that he will again become a dead man working.

The quiet walk into the night and the pinning of the hero within the frame during the apparently mundane interview are indicative of how differently Cantet articulates the three violences within his film. In some ways, he might seem to resemble directors like the Dardennes: social and symbolic violences are brought to the surface, in his films as in theirs, when they are seen to play out across individuals and their mute but eloquent bodies. But while the Dardennes and others push subjective violences to their lethal limits to underscore the sheer brutality of objective violences, Cantet opts to dedramatise violence. As a result, we are less blinded by the homicidal, and more able to pay attention to the workings of the quiet but omnipresent systemic and symbolic violences that play out within the everyday. We see how Vincent gains approval from all around him - his parents, wife and friends - when they think he is about to get a prestigious job for the UN development agency in Geneva. We note too how those he recruits for his Ponzi investment scheme are in open admiration of his apparent success and insider knowledge of the spheres of highlevel finance, their approval bringing the ambient pressure for social recognition to the fore. Unsurprisingly, Vincent devotes much energy to producing a persona that will look and sound right. At the closing job interview, for example, he is obliged to retrospectively erase his attempt to desert the labour market and present himself as an ambitious management consultant with a logical career progression. At the same time, as he circulates in France and Geneva, he finds himself exposed, sometimes via CCTV, to the gaze of hotel employees and security men who inspect him to ensure he fits properly in the spaces of corporate and institutional circulation. He himself is seen to police the behaviour of his children to ensure that they conform to the norms of competitive individualism. Is his younger son selling his toys for less than they could fetch at the school fete? Is his older son able to impose himself on his opponent at judo? Because the film is not drawn to dramatic violences, it is much better able to probe this fine-grained but all-pervasive policing of norms, roles, appearances and behaviours and our complicity within it.

A similar analysis might be applied to the film's probing of the disciplinary power of debt. As we noted above, as soon as financial necessity and the desire to make nothing change for his family forces Vincent to borrow money from his father and friends, he opens himself up to inspection. He must produce a self that bears a convincing promise of reliable future repayment. His mobile phone, the tool that, in combination with his car, seemed to allow him to roam as he chose while retaining networked connectivity, now serves to reel him in as his friends question him about where their money has gone. The Vincent who had seemed so liberated at the start is gradually hemmed in (O'Shaughnessy 2014). Again, the 
absence of any one climactic moment of truth allows us to focus on the mechanisms of systemic and symbolic violence that constrain behaviours and the kinds of subjectivities that individuals are allowed to deploy.

What of suicide within these dynamics? The film primarily hovers between two of the three categories; suicide in the symbolic and in the real. Much of the film is essentially made up of the former: Vincent's failed attempt to kill the worker-in-the-self and to cut the symbolic ties that connect him to the existing order. His problem is that he is never able to break free from his desire for social recognition or his attachment to material prosperity for himself and his family. He wants to escape the existing order while remaining valued within it. In other words, paradoxically, but consistent with the film's broader move to dedramatise violence, Vincent's suicide is not violent enough. He leaves himself trapped. The logical outcome is the implied, abortive suicide, the suicide in the real. Having failed to detach himself sufficiently from the 'failed object', the 'good' worker and bread-winner inside himself, the only way he can kill that which oppresses him is to take his own life, a gesture from which, as we know, the love of his family forces him back.

The film is in no way moralising. It contains no villains and victims, no monstrosity and innocence, no static and sterile oppositions. While many films, especially but not only Hollywood ones, tend to figure the personal and familial as being in opposition to inhuman systemic logics, L'Emploi du temps shows how the mechanisms of social discipline are fully at work in intimate relationships, sincerely felt love, we remember, being what draws Vincent back into conformity. Nor can the film be seen to offer an ethical way through the problems it raises. To the extent that it is about insufficiently radical work upon the self, it could be viewed as a work about an ethical failure, but that is clearly not its main thrust. What it does quite brilliantly, and this is where its political virtue lies, is to force us to confront how deeply we are tied into systemic and symbolic violences, to the extent of becoming active agents of their enforcement upon ourselves and others.

A more successful work upon the self can be found in Le Grand Soir. Like other films considered, Kervern and Delépine's anarchic comedy contains more than one type of suicide. The knowingly stereotypical, if not parodic, variant is carried out by Jean-Pierre, the more conformist of the two socially dysfunctional brothers at the film's heart. Jean-Pierre is estranged from his wife and struggles unsuccessfully to combine the demands of work with his share of the childcare for his infant. His erratic behaviour becomes manic when his boss tells him that, given the context of the (economic) Crisis, not all workers will necessarily keep their jobs and he, Jean-Pierre, is not hitting his required sales targets. This pressure drives an increasingly desperate Jean-Pierre out into the rest of the out-of-town shopping centre where he works in search of customers whom he can persuade or, failing that, force to test the memory foam mattress sample that he is carrying with him. Following a manic outburst bouncing on beds in the shop, his sacking, the discovery that his wife has spent what remained in their shared account, and a comic and one-sided fight with a small tree, he douses himself in petrol, goes to the hypermarket in the shopping centre and sets light to himself while shouting 'justice!' None of those shopping pay the slightest attention to him. His attempt is, however, brought to a grotesque conclusion when the hypermarket sprinkler system is triggered, dousing the flames on his body. It is at this stage that he is taken in hand by his brother. The latter gives the singed man a punk haircut, not without leaving blood encrusted on the side of his head, tattoos the word 'dead' on his forehead, gets him to shed his tie and teaches him how to walk in a relaxed and free manner, open to the world around him. 
INSERT FIGURE 4

Figure 4: Crying out to the big Other who is not listening (Ad Vitam).

The failed suicide clearly matches Cedeström and Fleming's suicide in the imaginary. Using the tormented worker's body to force the subjective experience of systemic violence into view, it seeks to appeal to a big other who is clearly not listening (see Figure 4). But the suicide's damp and derisory failure opens a route to a more productive suicide in the symbolic. Not, who has his name, with its proclamation of open-ended refusal, tattooed on his forehead, has already blazed the trail in his own scandalous way. With his Mohican haircut, punk attire, mongrel dog and loud, non-conformist behaviour, he is a walking declaration of unemployability. He is not simply on the margins of mainstream society. He is a disruptive presence at the heart of it and a direct challenge to it. He hangs around in the shopping centre, trolley-surfing, begging aggressively, practicing his punk dancing in front of a fast-food outlet, watched by the bemused consumers on the other side of the mirror glass. He sleeps with his dog in a Wendy house in a children's area and showers naked in a fountain by a busy road junction. He effectively performs a prolonged symbolic suicide, killing the docile worker, consumer and any other 'respectable' person inside himself. He is thus eminently suited to be his brother's guide as the latter learns to follow the same liberatory path of slow, symbolic self-immolation. Tellingly, when the two brothers stand side-by-side, after the failed suicide and the amateur tattoo, their two foreheads spell out 'not dead' (see Figure 5). Although, they have committed symbolic suicide, they are also still alive and thus able to explore new modes of life for themselves and others.

\section{INSERT FIGURE 5}

Figure 5: The not dead in search of another life (Ad Vitam).

It is at this stage that we can turn to Foucault and his painstaking discussion of parrhesia in his final Collège de France lectures, gathered together in The Courage of Truth: the Government of Self and Others II (2011). Pinning down the specificity of parrhesia, Foucault distinguishes it from other forms of truth-telling, such as wisdom or teaching. While wisdom is withdrawn and restrained, and teaching is a transmission of acquired knowledge about the world, parrhesia is a risk-taking truthfulness that exposes its exponent to potentially mortal danger. Although it can be traced in more than one philosophical or religious tradition, it is perhaps most fully developed in the Greek Cynics and in cynical thinkers such as Diogenes. The Cynics, as Foucault sees it, served as scouts for the rest of society; that is, they went ahead of others, searching out the forms of, not an other-worldly life, but another, truer life in this world (Foucault 2011, 159-167, 244-245). For this reason, the Cynic must travel light, like a beggar, detached from household, family, hearth or country. This shedding of attachments frees the cynical parrhesiac to tell the truth and strips away superfluous things which would serve as obstacles to clear-sightedness. A denuded existence is not simply in harmony with the Cynics' vision of the true life. It is a necessary pre-condition of its attainment. The Cynic does not merely proclaim a disruptive and unwelcome truth but bears witness to it in all aspects of his appearance and behaviour, wilfully challenging convention in public (Foucault 2011, 170-173). This scandalous attitude 
exposed someone like Diogenes to comparison to animals, notably dogs. Unperturbed, the Cynic embraces this judgement: just as the dog is shameless, immodest and indifferent to human respect, so too must he be (Foucault 2011, 242-243).

The multiple resemblances between Not and the Cynics are illuminating but unsurprising. The film-makers' creation of the character was openly inspired by their desire to create a contemporary Diogenes, a scandalous and courageous teller of unwelcome truths that would be embodied in his way of living and taught to others no matter how much it annoyed or angered them (Kervern and Delépine 2012, 192). Not's clear affinity with his dog is an open acknowledgement of this classical Greek lineage. In the same way as Diogenes and the Cynics sought to point the way to another life in this world, Not shows his brother how to kill his existing self without abandoning this life, or, in other words, how to carry out a suicide in the symbolic that is liberatory not mortal. Yet he is also aware of the limits to the transformational work that they are carrying out. This is the explanation for the film's title, Le Grand Soir, with its ironic evocation of a longed-for revolution that will finally transform not my life, or another's life, but life in general. As the film nears its conclusion, Not goes to hypermarket where his brother failed to kill himself, grabs the public address microphone and proceeds to call the shoppers to rise up, explaining how hard it is for him, as an individual rebel, to carry on alone. When he and his brother go to the site named for the proposed revolutionary gathering, a disused car-park, they find no-one has come. Foucault noted that

the Cynic addresses all men. He shows all men that they are leading a life other than the one they should be leading. And thereby it is a whole other world which has to emerge, or at any rate be on the horizon, be the objective of this Cynic practice. (Foucault 2011, 315)

What makes Le Grand Soir such an interesting film politically is its awareness of the gap between ethical work on the self, ethical commitment to a singular other, and such a broader transformation of life. This, ultimately, is what is lacking in both Cazeneuve's Seule and the two Dardenne brothers' films discussed earlier. Focused above all on their characters' ethical commitments to the dead or vulnerable other, they pay insufficient attention to the (scandalous) work on the self that is needed for a willed exit from neoliberal labour. Nor do they pay sufficient attention to the limits of an ethical commitment that fails to think itself alongside an aspiration to a broader transformation of the systemic conditions that create the localised, subjective violences that the characters react against in the first place. Rather more consistent and clear-sighted in its thrust, L'Emploi du temps confronts us with the necessary failure of any purely individual exit from the contemporary order. It also reminds us that work on the self, when harnessed to the avoidance of scandal, can stitch us back into our existing life rather than opening the space of the new.

\section{Conclusion}

In his recent book Heroes, 'Bifo' Berardi suggests that suicide waves and mass killing sprees are not simply isolated occurrences but offer a privileged vantage point from which to view the pathologies of financial capitalism and the exclusionary identitarian reactions that accompany it $(2015,2-3)$. Along similar lines, I hope I have shown that worker suicide films are not simply a disparate and relatively minor sub-group of work-related cinema but 
provide a privileged vantage point for viewing the current moment and cultural responses to it.

I suggested elsewhere that, beginning in around 1995, French and francophone Belgian cinema witnessed a profound shift in the framing of struggle whereby stories of mediated, collective mobilisation gave way to narratives within which systemic forces collided directly with often mute but also eloquent individual bodies (O'Shaughnessy 2007). The suicide films that I have discussed here can be seen as part of that broader trend but also as a radicalisation of the kind of crisis that it expressed. The way in which the films articulate subjective, symbolic and systemic violences to force the latter pair into view is typical of that broader body of works. But the recurrent figure of the suicidal worker suggests both a more emphatic sense of the murderousness of neo-liberal capitalism and a further closing in of historical horizons, especially where the worker in question is a representative of the working class, a social group once associated so strongly with a promise of radical change. Where the suicidal worker is not proletarian, as for example in Seule or L'Emploi du temps, the symbolic resonances shift; rather than suggesting the demise or erasure of a class, the suicides (or attempted suicides), point to a wider crisis of neo-liberal subjectivity as figures (managers, management consultants) whom one might have expected to be heroic, neoliberal entrepreneurs-of-the-self mutate into characters oppressed by their labour or in search of escape.

A good number of the films can find no positive exit from labour. As I have suggested, their main symbolic work focuses on turning suicides or suicide attempts into denunciations of murderous systemic logics, either by amplifying the message the acts already seek to deliver or by endowing them with an eloquence that they themselves lack by forcing their causes into the open. Other films, more than simply critical in their thrust, portray failed suicides that open up at least the possibility of a killing of the worker-in-the-self, an escape from neo-liberal labour and its logics. Amongst this latter group, the more interesting works, I have suggested, are those which probe all that ties us into neo-liberal subjectivities or which explore the difficulty of any individual exit while at the same time seeking to imagine what a life outside of neo-liberal labour, no matter how scandalous, might look like.

If the films collectively highlight the absence of meaningful political alternatives, not all do so in an equally self-conscious way. The recourse of many of them to either moralising stories, which pit vulnerable employees against monstrous employers, or to austere but ultimately sterile ethical narratives is eloquent in its own way. We know, of course, that not all films from a given moment will be equally politically far-sighted. The way in which current works hesitate between lucid pessimism and an ultimately unproductive moralising or ethical framing nonetheless speaks particularly eloquently of our current crisis of political imagination. At the same time, French and francophone Belgian cinema seems to struggle to find new formal strategies. If, around when Rosetta burst onto the scene in 1999, a newly raw cinema of individual, embodied struggle seemed to speak urgently to its moment, now we risk being trapped in the repetitive and moralising rediscovery of how bad things are, with each new film forcing to the surface violences of which we are only too aware. This may indicate a lack of creativity on the part of film-makers. It is also undoubtedly due to the continued domination of neo-liberalism, now well into its transparently punitive austerity phase. We urgently need films that can help us imagine or uncover alternatives. The big exit still beckons.

\section{Contributor details}


Martin O'Shaughnessy is Professor of Film Studies at Nottingham Trent University. He is the author of Jean Renoir (2000), The New Face of Political Cinema (2007), La Grande Illusion (2009), and Laurent Cantet (2015). He is particularly interested in contemporary cinema and politics and is working on a book on French and Francophone Belgian cinema in the current crisis.

\section{Filmography}

Article 23, 2012, Jean-Pierre Delépine, France. Carole Matthieu, 2016, Louis-Julien Petit, France. Corporate, 2017, Nicolas Silhol, France.

De bon matin, 2011, Jean-Marc Moutout, 2010.

Deux jours, une nuit, 2014, Luc and Jean-Pierre Dardenne, Belgium/France/Italy.

L'Emploi du temps, 2011, Laurent Cantet, France.

Le Grand Soir, 2012, Gustave Kervern and Benoît Delépine, France/Belgium/Germany.

Kuhle Wampe, 1932, Slatan Dudow, Germany.

La Loi du marché, 2015, Stephane Brizé, France.

Ma part du gâteau, 2011, Cédric Klapisch, France.

Near death experience, 2014, Gustave Kervern and Benoît Delépine, France.

Le Père de mes enfants, 2009, Mia Hansen-Løve, France/Germany/Belgium.

La Question humaine, 2007, Nikolas Klotz, France.

Rosetta, 1999, Luc and Jean-Pierre Dardenne, France/Belgium.

Sauf le respect que je vous dois 2005, Francois Godet, France.

Selon Matthieu, 2000, Xavier Beauvois, France.

Seule, 2008, Fabrice Cazeneuve, France.

Strike, 1925, Sergei Eisenstein, USSR.

La Vie rêvée des anges, 1998, Erick Zonca,

\section{Works cited}

Arendt, Hannah. 1970. On Violence. Orlando: Harcourt.

Badiou, Alain. 2003. L'Ethique: essai sur la conscience du mal. Caen: Nous.

Berardi, Franco ‘Bifo.' 2015. Heroes: Mass Murder and Suicide. London: Verso.

Brown, Wendy. 2001. Politics out of History. Princeton: Princeton University Press.

Cedeström, Carl and Peter Fleming. 2012. Dead Man Working. Winchester: Zero Books.

De Gaulejac, Vincent. 2015. Travail: les raisons de la colère. Paris: Points.

Delépine, Benoît and Gustave Kervern. 2012. De Groland au Grand Soir: entretien avec Hervé Aubron et Emmanuel Burdeau, Nantes: Editions Capricci.

Dejours, Christophe and Bègue. 2009. Suicide et travail: que faire?. Paris: Presses Universitaires de France. 
Foucault, Michel. 2011. The Courage of Truth, the Government of Self and Others II: Lectures at the College de France, 1983-1984 (translated by Graham Burchell). New York:

Picador/Palgrave Macmillan.

O’Shaughnessy, Martin. 2007. The New Face of Political Cinema. Oxford: Berghahn.

O'Shaughnessy, Martin. 2010. "French Cinema and the Political." Studies in French Cinema 10(1): 39-56.

O'Shaughnessy, Martin. 2014. "The Crisis Before the Crisis: Reading Films by Laurent Cantet and Jean-Pierre and Luc Dardenne Through the Lens of Debt." SubStance, 43(1): 82-95.

Rancière, Jacques. 2008. Le Spectateur émancipé. Paris: La Fabrique.

Van der Linden, Harry. 2012. "On the Violence of Systemic Violence: A Critique of Slavoj Žižek." Radical Philosophy Review 15(1): 33-51.

Waters, Sarah. 2014. "A Capitalism that Kills: Workplace Suicides at France Telecom." French Politics, Culture and Society 32(3): 121-141.

Žižek, Slavoj. 2000. The Fragile Absolute - or Why is the Christian Legacy Worth Fighting for?. London: Verso.

Žižek, Slavoj. 2008. Violence: Six Sideways Reflections. London: Profile Books.

\footnotetext{
${ }^{1}$ One could also add to the list Erick Zonca's La Vie rêvée des anges/The Dreamlife of Angels (1998), a film that culminates in a suicide related to injuries of class in general (a precarious worker who kills herself when her relationship with a wealthy young man collapses) rather than work framed more narrowly.

${ }^{2}$ For an account of these debates see, for example, Waters (2014), Dejours and Bègue (2009), de Gaulejac (2015).
} 